\title{
Method for the simultaneous labelling of terminal deoxynucleotidyl transferase (TdT) and membrane antigens
}

\author{
J TAVARES DE CASTRO, JF SAN MIGUEL, J SOLER, D CATOVSKY \\ From the MRC Leukaemia Unit, Department of Haematology, Royal Postgraduate Medical School, \\ Hammersmith Hospital, London W12 OHS
}

SUMmARY A method for the simultaneous labelling of terminal deoxynucleotidyl transferase (TdT) and membrane antigens is described. TdT is visualised in the cell nucleus with the peroxidase-antiperoxidase (PAP) method, and the immunogold method is used in combination 9 with monoclonal antibodies against membrane antigens. The morphology of the labelled cells is $\rightarrow$ well preserved for analysis by light microscopy and the preparations obtained can be kept perma- $\subseteq$ nently. This method is useful for the analysis of mixed cell proliferations, particularly in leukaemias.

Microscopical observations that depend on two immunological markers and the morphological appearances of cells are important for the comparison of leukaemic cells with corresponding normal cell types. ${ }^{1}$ In acute leukaemia the most useful combinations involve the staining of the intracellular enzyme terminal deoxynucleotidyl transferase $(\mathrm{TdT})^{2}$ and one membrane antigen, such as the common acute lymphoblastic leukaemia (ALL) or HLA-DR antigens, which are usually performed by immunofluorescence methods.'

We report here a technique that combines the immunogold method $^{3}$ for the detection of membrane antigens with a peroxidase-antiperoxidase method (PAP) 4 for the demonstration of TdT and permits analysis by light microscopy. The advantages of this method are: $(a)$ the observations are made on conventional microscopes; $(b)$ the cell preparations are permanent; and $(c)$ the morphological detail is greater than with immunofluorescence preparations, hence facilitating the comparison of morphological characteristics with the immunologic phenotype of individual cells.

\section{Material and methods}

\section{CELLS AND ANTIBODIES}

The antibodies used and their specificities, sources, titres, and volumes applied are detailed in Table 1.

Accepted for publication 1 March 1984
To set up the technique, which is referred to as the combined technique, the NALM-1 cell line ${ }^{11}$ was used. This cell line, derived from a lymphoid blast crisis of chronic granulocytic leukaemia, expresses TdT, the common ALL antigen, and la-like deter- $\triangle$ minants. The procedure was then tested in samples $\overline{\vec{O}}$ from six patients with leukaemia, whose diagnoses 3 are listed in Table 2.

\section{COMBINED TECHNIQUE}

Cell separation

The mononuclear cell fraction from leukaemic samples (peripheral blood or bone marrow) was isolated by centrifugation at $400 \mathrm{~g}$ for $30 \mathrm{~min}$ on Lymphoprep (Nyegaard, Oslo, Norway). The cells were then washed, resuspended in buffer (phosphate buffered -aline (PBS), $1 \%$ bovine serum albumin, $0.2 \%$ ? sodium azide, $\mathrm{pH} 7 \cdot 4$ ), and counted.

\section{IMMUNOGOLD FOR SURFACE ANTIGENS}

In each test a pellet of $10^{\circ}$ cells was incubated with the relevant monoclonal antibody in the dilutions $\frac{\omega}{\sigma}$ and volumes detailed in Table 1 for $30 \mathrm{~min}$ at room temperature. After washing, $40 \mu \mathrm{l}$ of neat immunogold was added to the pellet and incubated $\$$ for $60 \mathrm{~min}$ at room temperature. The cells were then washed and cytocentrifuge preparations made with ${ }_{0}^{-}$ $2 \times 10^{5}$ cells per slide (Shandon Cytospin, $300 \mathrm{rpm}, \overrightarrow{\mathbb{D}}$ $7 \mathrm{~min})$. It is convenient to mark the cell area with $\mathrm{a} \frac{\rho}{\mathbb{Q}}$ diamond pen. At this stage the slides were dried and $\mathrm{Q}$ either stored at room temperature for some days 
Table 1 Immunological reagents

\begin{tabular}{|c|c|c|c|c|c|}
\hline Antibody & Specificity & Source & Titre & Volume & Reference \\
\hline J5 & Human common acute lymphoblastic & Coulter Electronics & Neat & $5 \mu V 10^{6}$ cells & 5 \\
\hline $\begin{array}{l}\text { OK1a } \\
\text { RFBI }\end{array}$ & $\begin{array}{l}\text { Human HLA-DR framework } \\
\text { Immature human haemopoietic cells } \\
\text { and } T \text { lineage cells }\end{array}$ & $\begin{array}{l}\text { Ortho, Raritan, New Jersey, USA } \\
\text { Dr MP Bodger } \\
\text { Department of Immunology, } \\
\text { Royal Free Hospital, London }\end{array}$ & $\begin{array}{l}\text { Neat } \\
1 / 100 \text { of } \\
\text { ascitic } \\
\text { fluid }\end{array}$ & $\begin{array}{r}5 \mu \mathrm{V} 10^{6} \text { cells } \\
50 \mu \mathrm{V} 10^{\circ} \text { cells }\end{array}$ & $\begin{array}{l}6 \\
7\end{array}$ \\
\hline FMC 8 & $\begin{array}{l}\text { Differentiation antigen expressed in } \\
\text { some human blood cells }\end{array}$ & $\begin{array}{l}\text { Dr H Zola } \\
\text { Flinders Medical Center, } \\
\text { Bedford Park, } \\
\text { South Australia }\end{array}$ & $\begin{array}{l}\text { Supernatant } \\
\text { as supplied }\end{array}$ & $50 \mu \mathrm{V} 10^{\circ}$ cells & 8 \\
\hline FMC 25 & Platelet membrane glycoprotein Ib & Dr H Zola & $\begin{array}{l}\text { Supernatant } \\
\text { as supplied }\end{array}$ & $50 \mu \mathrm{V} 10^{6}$ cells & 9 \\
\hline Immunogold & $\begin{array}{l}\text { Goat antibodies to mouse immuno- } \\
\text { globulin linked to } 40 \mathrm{~nm} \text { colloidal gold } \\
\text { particles }\end{array}$ & $\begin{array}{l}\text { Janssen Life Sciences Products, } \\
\text { Beerse, Belgium }\end{array}$ & Neat & $40 \mu \mathrm{V} 10^{\circ}$ cells & 3 \\
\hline Anti-TdT & Rabbit antiserum to calf $\mathbf{T d T}$ & $\begin{array}{l}\text { Professor FJ Bollum } \\
\text { Bethesda, Maryland, USA }\end{array}$ & $1 / 10$ & \multirow{2}{*}{\multicolumn{2}{|c|}{ 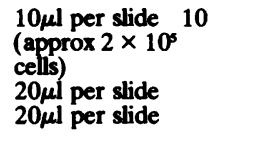 }} \\
\hline $\begin{array}{l}\text { Goat antirabbit } \\
\text { PAP complex }\end{array}$ & $\begin{array}{l}\text { Antirabbit IgG } \\
\text { Rabbit antiperoxidase complexed with } \\
\text { horseradish peroxidase }\end{array}$ & $\begin{array}{l}\text { Miles Laboratories, Slough } \\
\text { Bioproducts UCB, } \\
\text { Brussels, Belgium }\end{array}$ & $\begin{array}{l}1 / 200 \\
1 / 300\end{array}$ & & \\
\hline
\end{tabular}

Table 2 Comparison of the combined method with conventional immunofuorescence methods in samples from patients with leukaemia

\begin{tabular}{|c|c|c|c|c|c|c|c|}
\hline \multirow[t]{2}{*}{ Ċase } & \multirow[t]{2}{*}{ Diagnosis } & \multicolumn{6}{|c|}{ Percentage of positive cells* } \\
\hline & & $T d T$ & $J 5$ & OKla & RFB1 & $F M C 8$ & $F M C 25$ \\
\hline 1 & \multirow{4}{*}{$\begin{array}{l}\text { Mixed BC } \\
\text { Myeloblastic + lymphoid } \\
\text { + megakaryoblastic } \\
\text { Lymphoid BC } \\
\text { Mixed BC } \\
\text { Lymphoid + myeloblastic } \\
\text { Lymphoid BC } \\
\text { Mixed acute leukaemia } \\
\text { Lymphoid + myeloblastic } \\
\text { c-ALL }\end{array}$} & $10(10)$ & & $65(70)$ & & $42(50)$ & $25(33)$ \\
\hline $\begin{array}{l}2 \\
3\end{array}$ & & $\begin{array}{l}69(94) \\
64(63)\end{array}$ & $\begin{array}{l}98(93) \\
10(13)\end{array}$ & $\begin{array}{l}56(62) \\
80(64)\end{array}$ & $73(90)$ & $100(95)$ & \\
\hline $\begin{array}{l}4 \\
5\end{array}$ & & $\begin{array}{l}90(86) \\
80(70)\end{array}$ & $\begin{array}{c}97(95) \\
6(8)\end{array}$ & $\begin{array}{r}100(82) \\
25(60)\end{array}$ & $92(98)$ & & \\
\hline 6 & & $88(92)$ & $62(96)$ & & & & \\
\hline
\end{tabular}

$\mathrm{BC}=$ blast crisis of chronic granulocytic leukaemia.

c-ALL = common acute lymphoblastic leukaemia.

*Percentages for combined method (immunofluorescence results in brackets).

(maximum one week) or processed immediately for TdT.

\section{PAP technique for TdT}

Fixation was done in methanol at $4^{\circ} \mathrm{C}$ for $45 \mathrm{~min}$. After fixation, slides were washed in PBS for $10 \mathrm{~min}$ in a container with buffer and a magnetic stirrer. The cells were incubated successively with anti-TdT, goat antirabbit immunoglobulin, and PAP complex. The $30 \mathrm{~min}$ incubations were done at room temperature in a moist chamber and each was followed by washes in PBS.

After the last wash, slides were briefly immersed in Tris- $\mathrm{HCl}$ buffer $(0.05 \mathrm{M}$ Tris- $\mathrm{HCl} 0.9 \% \mathrm{NaCl}$, $\mathrm{pH} \mathrm{7.4)}$ and peroxidase activity was developed by immersion for $10 \mathrm{~min}$ at room temperature in the dark in diaminobenzidine medium: $0.3 \mathrm{mg} / \mathrm{ml}$ diaminobenzidine (Aldrich Chemical Co, Gillingham, UK), $0.03 \% \mathrm{H}_{2} \mathrm{O}_{2}$ in Tris- $\mathrm{HCl}$ buffer.

\section{Counterstaining and mounting}

After washing with Tris- $\mathrm{HCl}$ buffer and a brief immersion in distilled water, the cells were counterstained with $1 \%$ methyl green (5-10 min), washed in water, dehydrated by immersion in graded ethanols $(50,70,90$, absolute ethanol), cleared with xylene, and mounted permanently with DPX (Raymond Lamb, London). The preparations were examined with a conventional light microscope.

\section{Endogenous peroxidase}

Endogenous peroxidase could be blocked by immersion in $0.3 \% \mathrm{H}_{2} \mathrm{O}_{2}$ in methanol for $30 \mathrm{~min}$ immediately after fixation.

\section{Controls}

For negative controls either the monoclonal antibody in the first step, the anti-TdT in the second, or both were omitted. We tested the samples by con- 


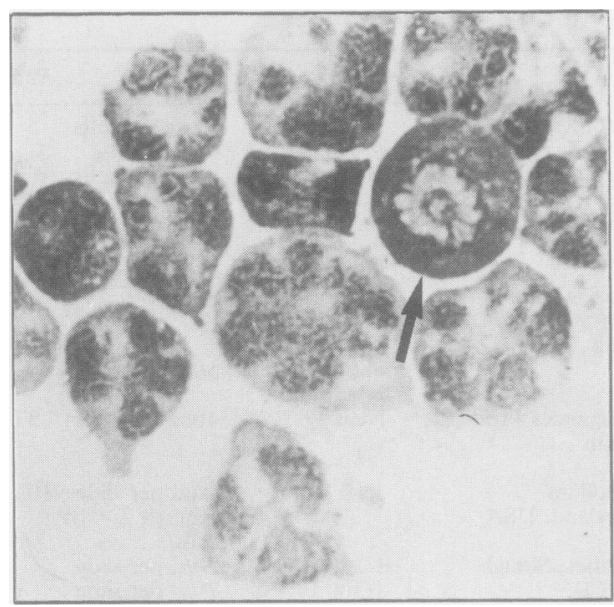

Fig. 1 Nalm-1 cells. TdT detection by the peroxidase-antiperoxidase method. The reaction is present mainly in the nucleus. A dividing cell shows the reaction diffusely distributed in the cytoplasm, but absent in the area containing the chromosomes (arrow). $\times 1000$.

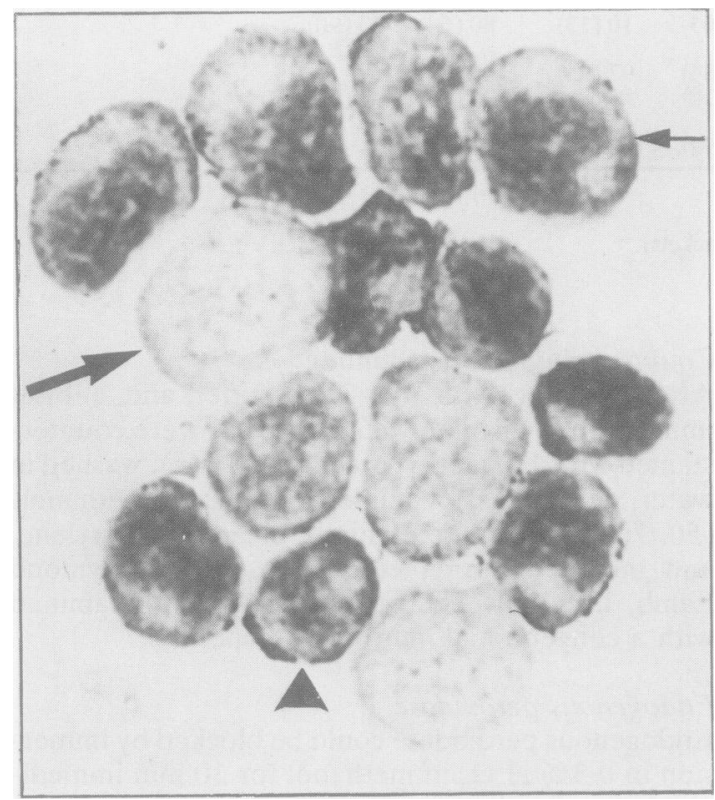

Fig. 2 Case 3, combined method: TdT and J5. Large blasts are TdT negative, J5 negative (large arrow); medium size blasts TdT positive, predominantly J5 negative (small arrow); and small blasts TdT positive, predominantly J5 positive (arrow head). TdT reaction is stronger in small blasts. Original magnification $\times 1000$. ventional immunofluorescence for TdT and the relevant surface antigens. Table 2 shows a compari- 을 son of the results with those obtained by the new method.

\section{Results}

The percentage of positive cells by the combined technique correlated well with the results obtained by conventional immunofluorescence methods with similar reagents (Table 2 ). TdT was detected as a $\vec{\omega}$ brown reaction present in the nucleus in a fine par- $O$ ticular pattern. The intensity of reaction varied from $\frac{8}{8}$ cell to cell. In some cells a weak reaction was also present in the cytoplasm. In dividing cells the reac- os tion was diffusely distributed through the cytoplasm, with the area containing the chromosomes devoid of $\infty$ reactivity (Fig. 1). In leukaemic samples the $\mathrm{TdT}$ 윽 reaction tended to be stronger in small blasts with a lymphoid appearance (Fig. 2). Inhibition of $\subseteq$ endogenous peroxidase with $\mathrm{H}_{2} \mathrm{O}_{2}$ weakened the $\stackrel{\vec{D}}{\vec{D}}$ TdT reaction. When this procedure was not used $\overrightarrow{0}$ rare erythrocytes and myeloid cells were positive; $\stackrel{\infty}{\oplus}$ this did not constitute a problem because they could be recognised morphologically. Cells reacting with the monoclonal antibodies had numerous black dots around the surface membrane. In the strongly reactive cells these dots were confluent and covered variable sections of the cell surface as a black lining (Fig. 3). Most of the unreactive cells had no dots. Cells with fewer than three dots were considered negative. Ultrastructural studies (results not shown) have shown that the individual dots correspond to patches of $40 \mathrm{~nm}$ colloidal gold particles. ${ }^{12}$

The combined method was particularly useful for analysing the cellular components of leukaemias 3 with different types of blasts (cases $1,3,5$ ), characteristically seen in mixed acute leukaemias and mixed blast crisis of chronic granulocytic leukaemia. In case $1 \mathrm{TdT}$ positive blasts also expressed the antigens recognised by OKla and FMC 8 , but the anti- $\frac{D}{2}$ platelet antibody FMC25 reacted only with TdT negative blasts. In cases 3 and 5 with mixtures of 0 myeloblasts and lymphoblasts large blasts were TdT $N$ negative, J5 negative, and RFBl positive; medium N size blasts were $\mathrm{TdT}$ positive, predominantly $\mathrm{J} 5 \frac{\mathrm{W}}{\sigma}$ negative, and RFBl positive; and small cells were TdT positive, predominantly J5 positive, and RFBI positive (Figs. 2 and 3 ). In the control preparations $\stackrel{D}{\rightarrow}$ all the cells were negative for the omitted antibody. The percentage of positive cells was the same in experiments where the two steps of the technique $\overrightarrow{\mathbb{D}}$ were performed separately and in combination, $\frac{?}{\overparen{ }}$ which shows that they do not interfere with each $\frac{0}{\sigma}$ other. 


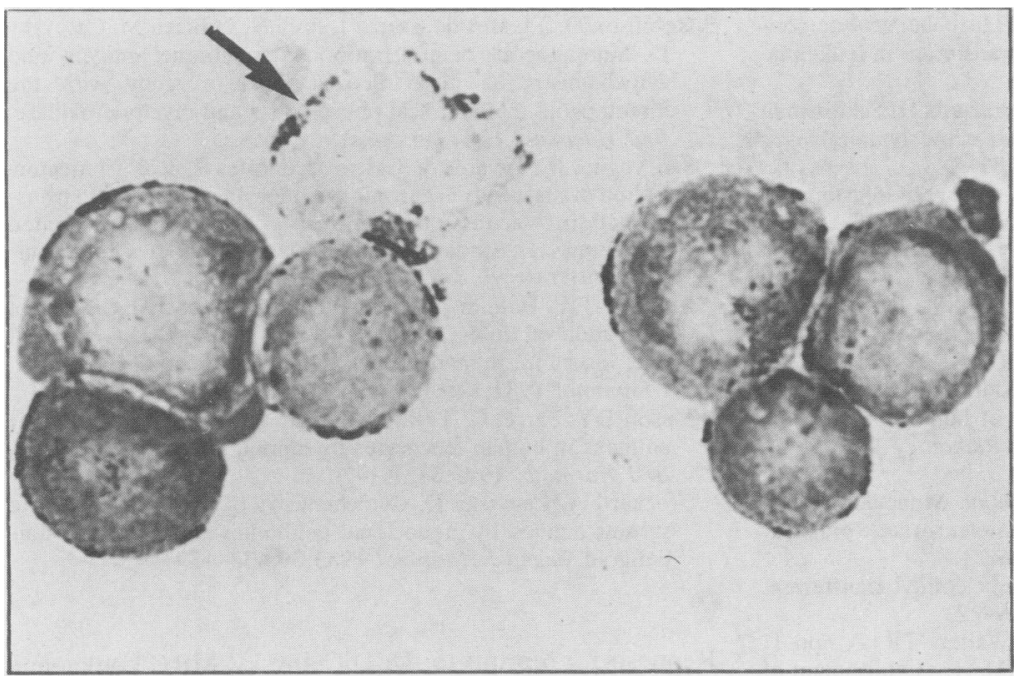

Fig. 3 Case 5, combined method: TdT and RFBl. One large blast is $R F B l$ positive, $T d T$ negative (arrow), the other blasts express both markers. Original magnification $\times 1000$.

\section{Discussion}

Although more time consuming than conventional immunofluorescence methods this technique requires only the use of a simple light microscope and provides permanent preparations. We found a good correlation between the combined technique and conventional immunofluorescence methods both for TdT and surface antigens, and the specificity of both components of the method was also good as a positive reaction in the controls was never seen. The morphological detail obtained was good and from each single cell it was possible to obtain three types of information: morphology and expression of TdT or of a membrane antigen, or both.

This method is particularly useful in the study of mixed leukaemias and blast crisis of chronic granulocytic leukaemia, where frequently two or more different populations of blasts coexist. ${ }^{13}$ In these cases it is possible: (a) to analyse the different morphological characteristics of the blasts that correspond to each of the immunological phenotypes present (cases 3 and 5), and (b) to determine if TdT and a membrane marker can be simultaneously present in the same cell or are always expressed in different blasts (case 1). This technique can be used for the analysis of single cells in certain tissues-for example, cerebrospinal fluid and remission bone marrow-where it may help identify cells with a leukaemic membrane phenotype and thus distinguish them from putative normal precursors.' Another possible area of application could be in the studies of in vitro differentiation of lymphoid cell lines, where changes in the expression of two markers could be correlated with the morphological evolution. ${ }^{14}$

In the present work we studied the expression of five different surface antigens: the same approach could be extended to any cell membrane antigen detectable by a monoclonal antibody or heteroantisera. A possible variant of the technique is the detection of cytoplasmic immunoglobulin ${ }^{15}$ instead of $\mathrm{TdT}$ and its association with the membrane phenotype as shown by the immunogold technique. The combination of the immunogold technique with cytochemistry has been reported from this laboratory both in studies by light microscopy ${ }^{16}$ and by electron microscopy. ${ }^{12}$

We are grateful to Professor FJ Bollum for the gift of anti-TdT, Dr MF Greaves for the Nalm-l cell line, Dr HP Bodger for the RFBl, and Dr H Zola for the FMC8 and FMC25 monoclonal antibodies. JTC was supported by the Calouste Gulbenkian Foundation, Portugal, and JFSM by the Science and Education Ministry of Spain.

\section{References}

' Janossy G, Bollum FJ, Bradstock KF, Ashley J. Cellular phenotypes of normal and leukemic hemopoietic cells determined by analysis with selected antibody combinations. Blood 1980;56:430-41.

${ }^{2}$ Bollum FJ. Terminal deoxynucleotidyl transferase as a hematopoietic cell marker. Blood 1979;54:1203-15.

${ }^{3}$ De Waele M, De Mey J, Moeremans M, De Brabander M, Van Camp B. Immunogold staining method for the light microscopic detection of leukocyte cell surface antigens with monoclonal antibodies: its application to the enumeration of lymphocyte subpopulations. J Histochem Cytochem 1982;31:376-81. 
${ }^{4}$ Hecht T, Forman SJ, Winkler US, et al. Histochemical demonstration of terminal deoxynucleotidyl transferase in leukemia. Blood 1981;58:856-8.

${ }^{5}$ Ritz J, Pesando JM, Notis-McConarty J, Lazarus H, Schlossman SF. A monoclonal antibody to human acute lymphoblastic leukaemia antigen. Nature 1980;283:583-5.

- Reinherz EL, Kung PC, Pesando JM, Ritz J, Goldstein G, Schlossman SF. Ia determinants on human $T$-cell subsets defined by monoclonal antibody: activation stimuli required for expression. J Exp Med 1979;150:1472-82.

' Bodger MP, Francis GE, Delia D, Granger SM, Janossy G. A monoclonal antibody specific for immature human hemopoietic cells and T-lineage cells. J Immunol 1981;127:2269-74.

${ }^{8}$ Brooks DA, Bradley J, Zola $H$. A differentiation antigen expressed selectively by a proportion of human blood cells: detection with a monoclonal antibody. Pathology 1983;14:511.

' Zola H, McNamara PJ, Beckman IGR, et al. Monoclonal antibodies against antigens of the human platelet surface: preparation and properties. Pathology 1984;16:73-8.

${ }^{10}$ Bollum FJ. Antibody to terminal deoxynucleotidyl transferase. Proc Natl Acad Sci USA 1975;72:4119-22.

" Minowada J, Tsubota T, Greaves MF, Walters TR. A non-T, non-B human leukemia cell line (NALM-1): establishment of the cell line and presence of leukemia-associated antigens. $J$ Natl Cancer Inst 1977;59:83-7.
12 Robinson D, Tavares de Castro J, Polli N, O'Brien M, Catovsky D. Simultaneous demonstration of membrane antigens and cytochemistry at ultrastructural level: a study with the immunogold method, acid phosphatase and myeloperoxidase. Br J Haematol 1984 (in press).

${ }^{13}$ San Miguel JF, Tavares de Castro J, Matutes E, et al. Characterisation of blast cells in chronic granulocytic leukaemia in transformation, acute myelofibrosis and undifferentiated leukaemias. II. Studies with monoclonal antibodies and terminal transferase. Br J Haematol (submitted).

${ }^{14}$ Le Bien TW, Bollum FJ, Yasmineh WG, Kersey JH. Phorbol ester-induced differentiation of a non-T, non-B leukemic cell line: model for human lymphoid progenitor cell development. $J$ Immunol 1982;128:1316-20.

is Mason DY, Farrel C, Taylor CR. The detection of intracellular antigens in human leucocytes by immunoperoxidase staining. Br J Haematol 1975;31:361-70.

${ }^{10}$ Crockard A, Catovsky D. Cytochemistry of normal lymphocyte subsets defined by monoclonal antibodies and immunocolloidal gold. Scand J Haematol 1983;30:433-43.

Requests for reprints to: Dr D Catovsky, MRC Leukaemia $\stackrel{\bigcirc}{\triangle}$ Unit, Royal Postgraduate Medical School, Hammersmith Hospital, Ducane Road, London W12 0HS, England. 